\title{
Sitomorfolojik bulgularla pelvis renalisin üroteryal neoplazmı
}

\section{Urothelial neoplasm of pelvis renalis with cytomorphology findings}

\author{
Figen Barut* ${ }^{*}$, Gürkan Kertiş $a$, Burak Bahadır $a$, Şükrü Oğuz Özdamar $a$, Banu Doğan Gün $a$, İlker Seçkiner $^{b}$, \\ Gamze Mocan Kuzey ${ }^{c}$
}

${ }^{a}$ Karaelmas Üniversitesi Tıp Fakültesi Patoloji Anabilim Dal, Zonguldak

${ }^{b}$ Karaelmas Üniversitesi Tip Fakültesi Üroloji Anabilim Dalı, Zonguldak

${ }^{c}$ Hacettepe Üniversitesi Tip Fakültesi Patoloji Anabilim Dalı, Ankara

\section{MAKALE BÍLGILERI}

\section{Makale Geçmişi:}

Geliş

Kabul $01 / 07 / 08$

* Yazışma Adresi:

Figen Barut

Zonguldak Karaelmas Üniversitesi

Tıp Fakültesi Patoloji Anabilim Dalı, 67600, Kozlu, Zonguldak

E-posta : figenbarut@yahoo.com

\section{Anahtar Kelimeler:}

Sitoloji

Pelvis Renalis

Ürotelyal Neoplazi

\section{Key Words:}

Cytology

Pelvis Renalis

Urothelial Neoplasia

\section{ÖZET}

İdrar sitolojisi, sıklıkla mesanede izlenen üroteryal neoplaziler için kullanılan önemli bir tanısal tekniktir. Pelvikaliksiyel sistem ve üreter tümörlerinin tanısında sitopatolojik kanıtları ortaya koymak daha zor olmakla beraber sitolojik materyalde tümörün tanısı ve derecelendirilmesi, tedavi planlanmasında önemli avantaj sağlar.

Gross hematüri etyolojisi araştırılan 55 yaşında erkek hastanın, abdomen bilgisayarlı tomografisinde "sağ pelvis renalisde tümör?" saptanması üzerine yapılan üreterorenoskopisinde, pelvis renalisde multipl papiller kitle görünümü izlenmiştir. Bu işlem sırasında alınan idrar sitolojisi "malignite şüphesi” gösteren yayma olarak rapor edilmiştir. Doku örnekleri kesitlerinde, fibrovasküler kor çevresinde dizilim gösteren 6-7 epitel hücre tabakasından oluşan papiller yapılar ile karakterize tümöral oluşum izlenmiştir. Tümör, pleomorfik, iri, nükleolleri belirgin, hiperkromatik nükleuslu, eozinofilik sitoplazmalı atipik epitelyal karakterde hücrelerden oluşmaktadır. Lamina propriada invazyon saptanmayan olgu "düşük malign potansiyelli papiller üroteryal neoplazi (WHO/ISUP 98)" tanısı almıştır. Olgumuz diyagnostik sitolojik özellikleri nedeniyle sunulmaya değer bulunmuştur.

J. Exp. Clin. Med., 2009; 26:96-98

\begin{abstract}
Urine cytology is an important diagnostic technique for urothelial neoplasia. Although it is difficult to demonstrate the cytopathological clues in the diagnos are of pelvicalicial system and urothelial tumors, tumor grading and diagnosis with cytology provides important advantages for treatment. After "right pelvis renalis tumor?" determination in abdominal computerized tomography of a 55 year old male patient for gross hematuria etiology search, multiple milimetric papillary mass appearance was observed at pelvis renalis in ureterorenoscopy. In examination of urine sample obtained during this procedure reported as "suspicious of malignancy". A tumoral mass characterized with papillary structures composed of 6-7 epithelial cells layer lined around fibrovasculary core, is designated in cross sections. Tumor was composed of atypical epithelial cells with pleomorphic, coarse, apparent nucleoli, hyperchromatic nuclei and eosynophilic cytoplasm features. Tumor with no lamina propria invasion reported as "papillary urothelial neoplasm with low malignancy potential (WHO/ISSUP 98)" Our case was worth presentation because of its diagnostic cytological features.

J. Exp. Clin. Med., 2009; 26:96-98

(C) 2009 OMÜ Tüm Hakları Saklıdır.
\end{abstract}

\section{Giris}

İdrar sıvısının sitopatolojik incelemesi, böbrek kalikslerinden üretraya kadar üriner traktı döșeyen ürotelyal epitel hakkında bilgi verir ve tanı amaçlı kullanılır. Sanders, mesane kanseri tanısı düşündüren neoplastik hücre- lerin idrar sıvısına dökülebileceğini ilk kez 1864'de ortaya koymuştur. 1945 y1lında Papanicolaou, idrar sitolojisinin üriner trakt karsinomlarının tanısında önemli yer almasını sağlayan çalışmasını rapor etmiş ve şüpheli üriner trakt neoplazi olgularının araştırılmasında rutin işlemlere 
dahil edilmesini önermiştir (McKee, 2003). Son zamanlara kadar, üst üriner trakt ürotelyal neoplazilerinin tanıs1, ağırlıklı olarak retrograd pyelografi gibi dolum defektini gösteren ve tüm üriner traktı görüntülemede başarısız olan radyolojik çalışmalara dayanmıştır (Lodde ve ark., 2001). Üst üriner trakt ürotelyal karsinomlarının tanısı zor olmakla beraber, son günlerde gelişen endoskopik görüntüleme tekniklerinin kullanımı ile daha kolay hale gelmiştir. Özellikle bu teknikler ile elde edilen idrar sitolojisi, tanısal değeri yüksek bir materyal olmuş, tedavi sonrası olguların takibinde de kullanılmıştır (Lodde ve ark., 2001; Witte ve ark., 2002; McKee, 2003). İdrar sitolojisi, en sik mesanede izlenen üroteryal neoplazilerin tanısında büyük önem kazanmıştır. Pelvikaliksiyel sistem ve üreter tümörlerinin tanısında sitopatolojik kanıtları ortaya koymak mesane tümörlerine göre daha zor olmakla beraber, elde edilen sitolojik materyalde tümör tanısı ve derecelendirilmesi, tedavi planlanmasında önemli avantaj sağlar (Highman ve ark., 1986).

\section{Olgu Bildirimi}

Dokuz ay önce "gross" hematürisi olan 55 yaşında erkek hasta, etyolojinin araştırılması amacıyla hastanemiz üroloji kliniğine diş merkezden sevk edildi. Abdomen bilgisayarlı tomografisinde "sağ pelvis renalisde tümör?" saptanması üzerine yapılan sistoskopide, herhangi bir lezyona rastlanılmadi. Üreterorenoskopide ise, sağ pelvis renalis düzeyinde "saat 3-6-9" hizasında multiple milimetrik papiller kitle görünümü izlendi. $\mathrm{Bu}$ işlem s1rasında alınan idrar sitolojisinin incelenmesinde sellüler yaymalarda, küçük ve büyük gruplar halinde düşmüş, iri, hiperkromatik nükleuslu, eozinofilik sitoplâzmalı atipik epitelyal karakterde hücrelerden oluşmuş papiller yapılar

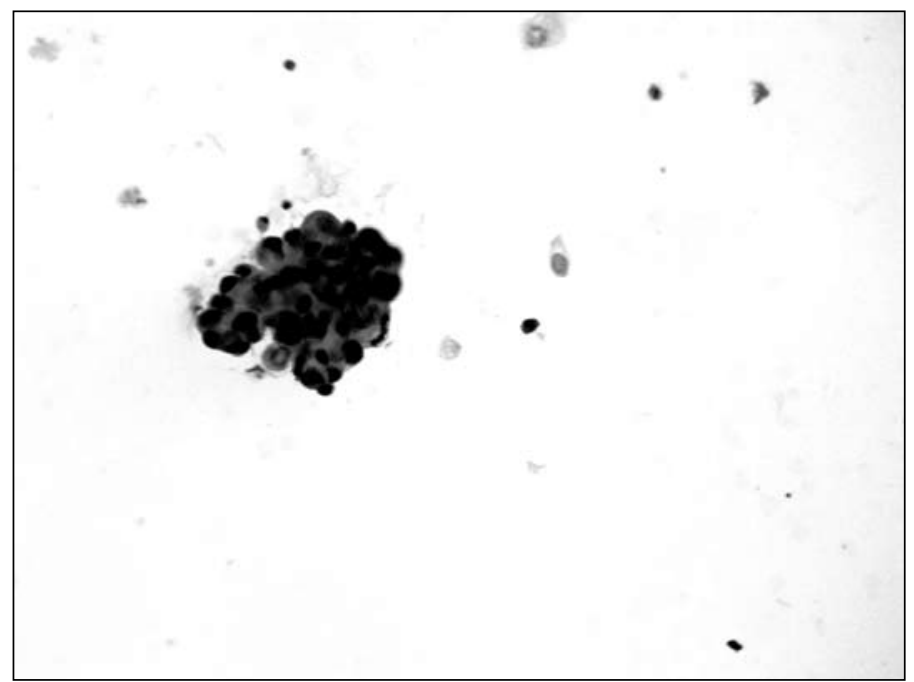

Şekil 1. Sellüler yaymada papiller yapılar oluşturmuş, mitoz içermeyen, pleomorfik, hiperkromatik nükleuslu, eozinofilik sitoplazmalı atipik ürotelyal hücreler (HE, X200).

izlendi ve "malignite şüphesi" gösteren yaymalar olarak rapor edildi (Şekil 1). Mesane kayıtlı sitoloji preparatlarında neoplastik üroteryal hücre izlenmedi. Eş zamanlı örneklenen "punch" biyopsi materyalinden hazırlanan doku kesitlerinde, ödemli fibrovasküler kor çevresinde dizilim gösteren 6-7 epitel kalınlığındaki hücre tabakasından oluşan papiller yapılar ile karakterize tümöral oluşum izlendi (Şekil 2). Tümör, iri, yer yer nükleolleri belirgin, hiperkromatik nükleuslu, eozinofilik sitoplâzmalı atipik epitelyal karakterde hücrelerden oluşmaktadır. Lamina propriada invazyon saptanmayan olguya "düşük malign potansiyelli papiller ürotelyal neoplazi (WHO/ISUP 98)" tanıs1 verildi.

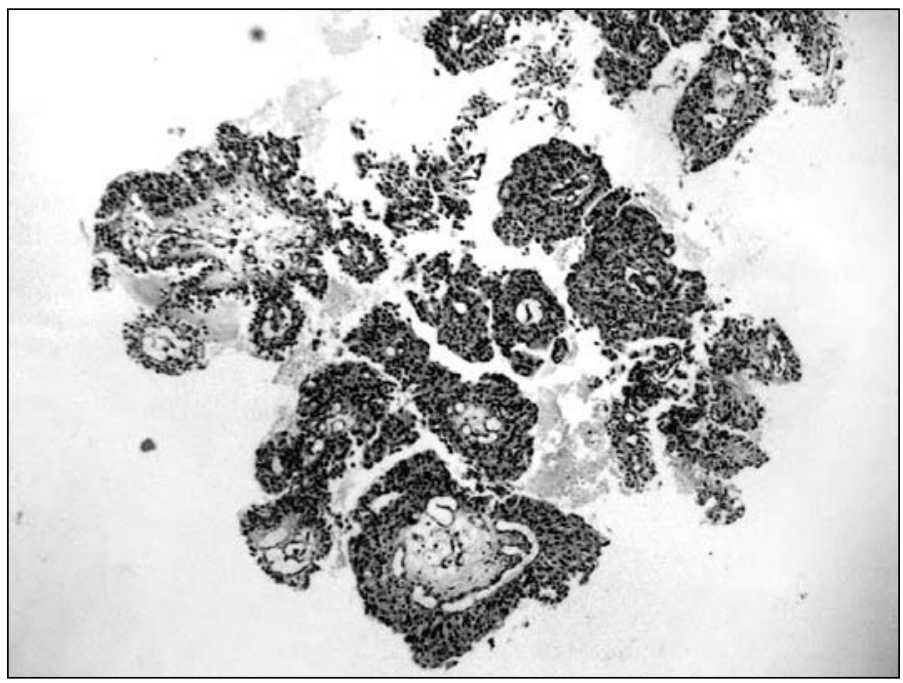

Şekil 2. Ödemli fibrovasküler kor çevresinde dizilim gösteren 6-7 epitel kalınlığındaki hücre tabakasından oluşan papiller yapılar ile karakterize tümöral oluşum (HE, X200).

Tanı sonrasında olgu, hastanemize tekrardan başvurmad1ğından tedavisi ve takibi yapılamadı.

\section{Tartışma ve Sonuç}

Üst üriner trakt ürotelyal karsinomları nadir bir neoplazm olup, tüm üroteryal karsinomların \%5-8'ini oluşturur (Dodd ve ark., 1997; Lodde ve ark., 2001; Witte ve ark., 2002; Mckee, 2003; Kirkali ve Tuzel, 2003; Park ve ark., 2004; Oehlschlager ve ark., 2004; Ordonez ve Rosai., 2004). Pelvis renalisin ürotelyal karsinomları, üreter neoplazilerinden 3-4 kat daha fazla oranda izlenirken, renal tümörlerin ise \%7-8'ini kapsar (Dodd ve ark., 1997; Lodde ve ark., 2001; Witte ve ark., 2002; Park ve ark., 2004).

Olguların \%2-4'ü bilateral olmakla beraber genelde sağ ve sol lokalizasyon arasında eşit dağılım görülür (Kirkali ve Tuze, 2003). Bu neoplazi, 50 yaş altında nadirken, olgumuzun yaşı ve cinsiyetiyle uyumlu olarak 6.- 7 . dekatlarda ve erkeklerde baskın olarak izlenir (Kirkali ve Tuzel, 2003; Ordonez ve Rosai, 2004).

Üst üriner trakt ve mesane ürotelyal neoplazileri, benzer risk faktörleri taşırlar ve aynı histomorfolojik özellikleri gösterirler. Yaş ve cinsiyet yanında sigara da önemli bir risk faktörüdür. Bunların dışında karsinojenler, uzun süreli analjezik ilaç kullanımı ve human papilloma virüs (HPV) infeksiyonu risk faktörü olarak bildirilmiştir (Kirkali ve Tuze, 2003; Ordonez ve Rosai; 2004).

Olgumuzun üroloji kliniğine başvurma nedeni olan "gross" veya mikroskopik hematüri en s1k gözlenen belirti olup, olguların \%75'inden daha fazlasında bulunurken; kitle, sık idrara çıkma ve kilo kaybı gibi belirtiler 
daha az siklıkla izlenir (Kirkali ve Tuzel, 2003; Ordonez ve Rosai, 2004). Erken tanı ve tedavi, renal parankim gibi derin dokulara invazyonun tespiti için önemlidir. Daha yaygın olarak kullanılan eksfolyatif sitoloji, pelvis renalis tümörlerinde düşük tanısal duyarlılığa ve özellikle de "düşük dereceli üroteryal karsinomların" tanısında yüksek yanlış negatiflik oranına sahiptir. Düşük dereceli neoplazilerde dökülen hücre sayısının az olmasının yanı sıra, sitolojik atipinin belirgin olmaması sitolojik tanıyı zorlaştıran faktörlerdir.

Üreterorenoskopi gibi ileri tekniklerin kullanımiyla elde edilen sitolojik materyal ve doku biyopsileri, tanısal duyarlılığı \%90'lara yükseltmiş, yanlış negatiflik oranını da düşürmüştür. Keeley ve ark. ları, çok sayıda alınan üreteroskopik biyopsiyi, üst üriner trakt lavajı ve bu sitolojik materyalden hazırlanan hücre bloğunun mikroskopik değerlendirilmesiyle birlikte kombine ettiklerinde, olguların \%94'ünde doğru tanıya ulaşmışlardır (Lodde ve ark., 2001). Sitolojik teknikler, sistoskopik bulgular ve doku incelemesi ile birlikte değerlendirildiğinde birbirini tamamlayan tanı yöntemleridir (Highman, 1986; Dodd ve ark., 1997). Üreterorenoskopi yöntemi ile elde edilen sitolojik ve biyopsi materyallerin patolojik tanıları olgumuzda uyumlu bulunmuş, birlikte değerlendirilmesi doğru tanı olasılığını arttırmıştır.

Tümörün evresi, derecesi ve tedavi şekli, üst üriner trakt üroteryal karsinomlarında sağkalımı belirleyen önemli prognoztik faktörlerdir. Bu faktörler dışında, tümör lokalizasyonunun da sağkalımı belirlemede etkili olabileceği birkaç çalışmada rapor edilmiştir (Dodd ve ark., 1997; Park ve ark., 2004; Ordonez ve Rosai, 2004; Holmang ve Johansson, 2005).

1973 World Health Organization (WHO) siniflamas1, üroteryal tümörlerin derecelendirilmesinde yaygın olarak kullanılmıştır (Ordonez ve Rosai, 2004; Holmang ve Johansson, 2005). Yeni siniflama sistemi olan, WHO/ International Society of Urological Pathologists (ISUP) sınıflaması, 1998'de yayınlanmış ve WHO 2004 sınıflama sistemi ile eşleştirilmiştir (Holmang ve Johansson, 2005).

$\mathrm{Bu}$ yeni sinıflama sistemi, mesane kanser serilerinde, tüm sınıflama sistemleri göz önünde bulundurularak değerlendirilmişken, üreter ve pelvis renalis tümörlerinde geniş kapsamlı bir çalışma yapılmamıştır. Holmang ve ark. ları çalışmalarında, üreter ve pelvis renalis tümörlerinde "over-diagnosis" den kaçınmayı ve farklı derecelendirmeler için daha iyi kriterler yaratmayı amaçlamışlar; bu tümörlerde "düşük malign potansiyelli papiller ürotelyal neoplazi” terimini tanımlamaya çalışmışlardır. Düşük malign potansiyelli papiller ürotelyal neoplazi terimi (Ordonez ve Rosai, 2004; Holmang ve Johansson, 2005) olgumuza ait doku örneğinin mikroskopik bulgusunda belirtildiği gibi sitolojik atipisi belirgin olmayan, tümör hücrelerinde hafif nükleer büyüme sergileyen, kalınlaşmış üroepitelyumdan oluşmuş tümöral lezyondur. Bu lezyonlar 1973 WHO s1nıflamasında derece 1'e dahil edilmiştir. Atipik özellikleri daha belirgin olan tümörler yeni sinıflamada malign neoplaziler olarak tanımlanmış; düşük veya yüksek dereceli karsinom olarak sınıflandırılmıştır (Ordonez ve Rosai, 2004; Holmang ve Johansson, 2005).

Tedavisinde radikal nefroüreterektomi uygulanan bu neoplazilerin klinik takibinde, \%12,5-38 oranında rekürrens bildirilmiştir (Park ve ark, 2004; Oehlschlager ve ark., 2004; Ordonez ve Rosai, 2004; Holmang ve Johansson, 2005).

Üreterorenoskopi tekniğiyle pelvis renalis düzeyinden elde edilen olgumuza ait idrar sitolojisi "malignite şüphesi" gösteren yaymalar olarak rapor edilmiş, eş zamanlı örneklenen "punch" biyopsisi de "düşük malign potansiyelli papiller ürotelyal neoplazi (WHO/ISUP 98)" tanısı almıştır. Bu bulgularla olguya "radikal nefroüreterektomi" planlanmış olmakla beraber, hastanemize başvurmamış olmasından dolayı klinik takibi yapılamamıştır.

Üst üriner trakt ürotelyal karsinomlarının tanısındaki güvenirlilik, klinisyen, radyolog ve sitopatolog arasındaki iletişime bağlı olmakta, özellikle de sitopatoloji anahtar rol oynamaktadır.

\section{KAYNAKLAR}

Dodd LG, Johnston WW, Robertson CN, Layfield LJ., 1997. Endoscopic brush cytology of the upper urinary tract. Evaluation of its efficacy and potential limitations in diagnosis. Acta Cytol. 41, 377-384.

Highman JW, 1986. Transitional carcinoma of the upper urinary tract: a histological and cytopathological study. J Clin Pathol. 39, 297-305.

Holmang S, Johansson SL, 1998. Urothelial carcinoma of the upper urinary tract: comparison between the WHO/ISUP consensus classification and WHO 1999 classification system. Urology 2005. 66, 274-278.

Kirkali Z, Tuzel E, 2003. Transitional cell carcinoma of the ureter and renal pelvis. Crit. Rev. Oncol. Hematol. 47, $155-169$.

Lodde M, Mian C, Wiener H, Haitel A, Pycha A, Marberger M, 2001. Detection of upper urinary tract transitional cell carcinoma with ImmunoCyt: a preliminary report. Urology 58, 362-366.

McKee G, 2003.Urinary tract cytology. In: Gray W (ed), Diagnostic Cytopathology. 2nd ed. China, Churchill Livingstone. 471497.

Park S, Hong B, Kim CS, 2004. Ahn H. The impact of tumor location on prognosis of transitional cell carcinoma of the upper urinary tract. J. Urol. 171, 621-625.

Oehlschläger S, Baldauf A, Wiessner D, Gellrich J, Hakenberg OW, Wirth MP, 2004. Bladder tumor recurrence after primary surgery for transitional cell arcinoma of the upper urinary tract. Urol. Int . 73, 209-21.

Ordonez NG, Rosai J, 2004. Urinary tract. In: Rosai J (ed), Rosai and Ackerman's urgical Pathology. 9th ed. China, Mosby. 11631359.

Witte D, Truong LD, Ramzy I, 2002. Transitional cell carcinoma of the renal pelvis the diagnostic role of pelvic washings. Am J Clin. Pathol. 117, 444-450. 